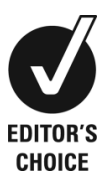

CHOICE

\title{
Unusual cause for gum hypertrophy and skin nodules in a child
}

\author{
Priyadharshini Rajendran, ${ }^{1}$ Balaganesh Karmegaraj, ${ }^{2}$ Mukul Vij, ${ }^{3}$ Julius Xavier Scott ${ }^{4}$
}

${ }^{1}$ Department of Pediatrics, Sri Ramachandra Medical College, Chennai, Tamil Nadu, India ${ }^{2}$ Department of Pediatrics, Ganesh Hospital, Tuticorin, Tamil Nadu, India

${ }^{3}$ Global Health City, Chennai, Tamil Nadu, India

${ }^{4}$ Department of Paediatric Hemato-Oncology, Sri Ramachandra University, Chennai, Tamil Nadu, India

\section{Correspondence to}

Dr Balaganesh Karmegaraj, kbgpho@gmail.com

Accepted 27 November 2015

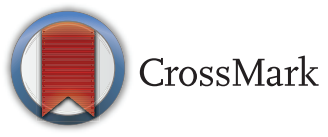

To cite: Rajendran $P_{\text {, }}$ Karmegaraj $B, V i j ~ M$, et al. BMJ Case Rep Published online: [please include Day Month Year] doi:10.1136/ bcr-2015-211506

\section{SUMMARY}

Juvenile hyaline fibromatosis (JHF) is a rare progressive autosomal recessive disease that is characterised by papulonodular skin lesions, soft tissue masses, joint contractures, gingival hypertrophy and osteolytic bone lesions. We present an 18-month-old boy with JHF. This case demonstrates that JHF should be considered in the differential diagnosis when multiple subcutaneous nodules are observed in the face, head and neck. Gum hypertrophy with palatal nodules is unusual in JHF.

\section{BACKGROUND}

Juvenile hyaline fibromatosis (JHF) is a rare hereditary disorder with mesenchymal dysplasia. The disease is characterised by multiple tumorous mucocutaneous proliferations, joint contractures, gingival hypertrophy and osteolytic lesions. It is hypothesised that JHF is a connective tissue disorder with a progressive nature. It requires repeated surgical interventions and physiotherapy. Rehabilitation and counselling of parents play an essential role in the treatment of these patients. Only about 70 cases of JHF have been reported worldwide to date. In the reported cases, nodules in the palate are very rare.

\section{CASE PRESENTATION}

An 18-month-old boy born to second-degree consanguineous parents was referred to our institution for the treatment of multiple scalp swellings and gingival hyperplasia with the suspicion of leukaemia. He had motor developmental delay, flexion contractures of both hips, widening of the wrists (figure 1A), gingival hypertrophy, a nodular lesion over the palate and verrucae on the dorsum of the tongue and at the oral commissure (Figure 1B) and multiple subcutaneous nodules over the scalp (figure 1C) since 6 months of age. There was no history of a similar illness in the family members. The parents initially sought medical advice at 8 months of age in view of the painless progressive enlargement of the scalp nodules and gingiva. The patient was undernourished due to feeding difficulties related to the nodule in the palate.

\section{INVESTIGATIONS}

Laboratory examination and investigation of other organs were normal. A skeletal survey did not reveal any significant abnormalities. MRI of the head confirmed the subcutaneous nature of the scalp lesions (figure 1D). The subcutaneous nodule was surgically removed and fixed in $10 \%$ buffered formalin for $24 \mathrm{~h}$. Whole tissue was embedded after routine processing. 3-5 $\mu \mathrm{m}$ sections were obtained and stained with H\&E and with additional stains such as periodic acid Schiff (PAS), PAS after diastase, orcein (for elastic fibres) and Alcian blue. Biopsy of the nodule revealed markedly thickened dermis with abundant eosinophilic matrix (figure 2A) and uniform fibroblast-like cells embedded in an abundant eosinophilic ground substance (figure 2B). The material was PAS positive and diastase resistant. The material did not stain with Alcian blue and it lacked elastic fibres. A diagnosis of JHF was therefore made.

\section{DIFFERENTIAL DIAGNOSIS}

\section{Gingival hypertrophy}

- Drugs (phenytoin, cyclosporine, nifedipine)

- Lysosomal disorders (especially Farber's and I cell disease)

- Infantile myofibromatosis

- Mucopolysaccharidosis

- Langerhan cell histiocytosis

- Leukaemia

- Tuberculosis

- Sarcoidosis

- Vitamin C deficiency

- Plasma cell gingivitis

\section{Subcutaneous nodules}

- Acute rheumatic fever

- Juvenile idiopathic arthritis

- Neuroblastoma

- Acute myeloid leukaemia

- Malignancies

- Panniculitis

- Granuloma annulare

\section{TREATMENT}

The parents were counselled regarding the nature of the disease. Surgical excision of the scalp lesions was advised but the parents did not bring the child for follow-up.

\section{OUTCOME AND FOLLOW-UP}

The patient was lost to follow-up.

\section{DISCUSSION}

$\mathrm{JHF}$ is an autosomal recessive disease characterised by gum hypertrophy, joint contractures, bone lesions and internal organ involvement. ${ }^{1}$ It was first described as molluscum fibrosum by McMurray in 1873 , later renamed as JHF by Kitano in $1972 .{ }^{2}$ It is characterised by deposition of amorphous hyaline material in the extracellular spaces of the dermis and soft tissues. Many case reports have 
Figure 1 (A) Widening of both wrists. (B) Gingival hypertrophy with a nodular lesion over the palate and verrucae on the dorsum of the tongue and at the oral commissure. (C) Multiple scalp nodules. (D) MRI head showing the subcutaneous nature of the nodules.
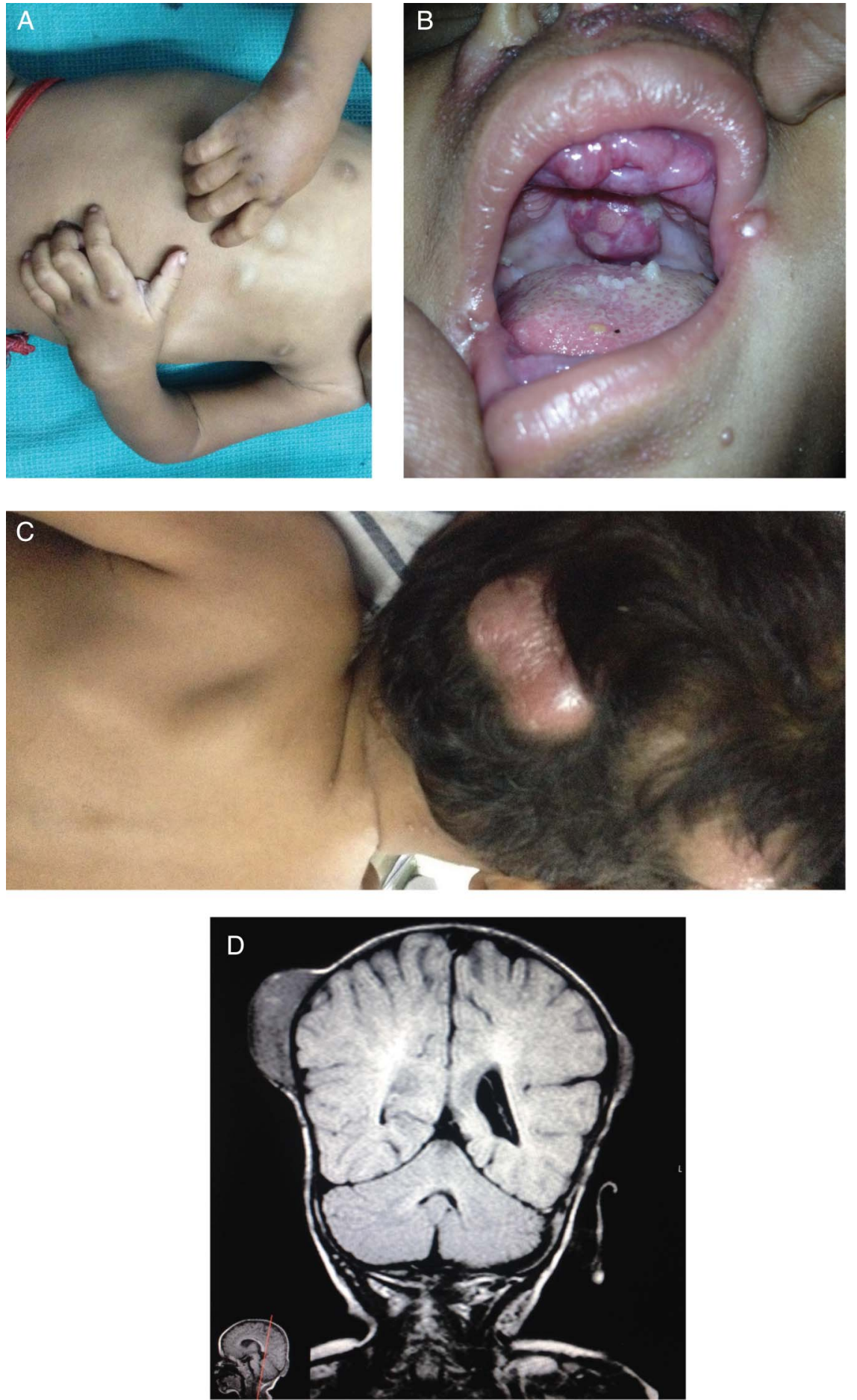

reported different metabolic defects such as procollagen, tropocollagen, glycosaminoglycans, hyaluronic acid, chondroitin sulfate, type I, III and VI collagen. ${ }^{3}$ It arises from mutation in the anthrax toxin receptor 2 gene on chromosome $4 \mathrm{q} 21 .{ }^{4}$

Although mucocutaneous nodules have been reported in the neck, elbow, knees, shins and ankles, a lesion in the palate has never been reported. Mucocutaneous lesions of the anal canal are associated with rectal bleeding. ${ }^{5}$ Affected children are mentally normal except for a few cases. ${ }^{6}$ Cosmetic and functional disability can be minimised by surgical excision of the lesions and physiotherapy to prevent joint contractures. The clinical criteria for resection of the lesions are functional impairment and ulceration of the lesion. Partial or radical gingivectomy followed by good oral hygiene can lead to resolution of hypertrophy; however, gingivectomy is usually followed by recurrence of the disorder. ${ }^{7}$ Although interferon $\alpha-2 \mathrm{~B}$ has been tried in $\mathrm{JHF}^{8}$ no definitive cure for JHF has yet been found. Other treatments for symptoms of joint involvement include cortisone, D-penicillamine and capsulotomy. Due to accumulation of abnormal materials in the soft tissues, severe airway problems can occur which may lead to anaesthetic complications. ${ }^{9}$ Death may occur due to pneumonia and respiratory failure due to peribronchial infiltrate and fibrous visceral pleural thickening.

Mutation, clinical features and histopathology are similar in infantile systemic hyalinosis (ISH) and JHF and therefore should be differentiated. JHF is a less severe late-onset disorder (after 



Figure 2 (A) Markedly thickened dermis with abundant eosinophilic matrix. (B) Uniform fibroblast-like cells embedded in an abundant eosinophilic ground substance.

3 months of age) and most children will survive until the fourth decade whereas ISH is a severe early-onset (few weeks of life) disorder which presents with short stature, failure to thrive, hyperpigmented plaques on bony prominences, persistent diarrhoea, visceral involvement, recurrent infections and death before 2 years of age. ${ }^{10}$

Since JHF and ISH share may common features, Nofal et al proposed the common term 'hyaline fibromatosis syndrome' with the following grading system: ${ }^{11}$

Grade 1: skin and/or gingival involvement only

Grade 2: grade $1+$ joint and/or bone involvement

Grade 3: grade $2+$ internal organ involvement with or without clinical manifestations
Grade 4: grade 3 + severe clinical decompensation (organ failure and/or septicaemia).

Our patient was grade 2 by clinical examination; however, complete assessment for involvement of internal organs was not done due to financial constraints and also because the parents were not willing.

\section{Learning points}

- Early diagnosis of juvenile hyaline fibromatosis (JHF) can prevent cosmetic and functional disability.

- Although manageable, recurrence after surgical excision is discouraging.

- JHF should be considered in the differential diagnosis when multiple subcutaneous nodules are observed in the face, head and neck.

- Gingival hypertrophy with palatal nodules is unusual in JHF.

Contributors PR prepared the manuscript. BK diagnosed the case, took clinical pictures and helped in preparing the manuscript. MV diagnosed the disease histopathologically. JXS diagnosed and managed the case, corrected the manuscript and helped in the review of the literature.

Competing interests None declared.

Patient consent Obtained.

Provenance and peer review Not commissioned; externally peer reviewed.

\section{REFERENCES}

1 Finlay AY, Ferguson SD, Holt PJA. Juvenile hyaline fibromatosis. $\mathrm{Br} J$ Dermatol 1983;108:609-16.

2 Rahman N, Dunstan M, Teare MD, et al. The gene for juvenile hyaline fibromatosis maps to chromosome 4q21. Am J Hum Genet 2002;71:975-80.

3 Breier $F$, Fang-Kircher $S$, Wolff $K$, et al. Juvenile hyaline fibromatosis: impaired collagen metabolism inhuman skin fibroblasts. Arch Dis Child 1997:77:436-40.

4 Wang YY, Wen CQ, Wei Z, et al. A novel splice site mutation in ANTXR2 (CMG2) gene results in systemic hyalinosis. J Pediatr Hematol Oncol 2011;33:e355-7.

5 Raja K, Khan MA, Mubarak M, et al. Three years old child with juvenile hyaline fibromatosis presenting with rectal bleeding. J Pak Med Assoc 2013;63:396-8.

6 Mestiri S, Labaied N, Mama N, et al. Juvenile hyaline fibromatosis: a case report. Pathologica 2014;106:70-2.

7 Uslu H, Bal N, Guzeldemir E, et al. Three siblings with juvenile hyaline fibromatosis. J Oral Pathol Med 2007;36:123-5.

8 Ruiz-Maldonado R, Durán-McKinster C, Sáez-de-Ocariz M, et al. Interferon alpha-2B in juvenile hyaline fibromatosis. Clin Exp Dermatol 2006;31:478-9.

9 Norman B, Soni N, Madden N. Anaesthesia and juvenile hyaline fibromatosis. Br J Anaesth 1996;76:163-6.

10 Denadai R, Raposo-Amaral CE, Bertola D, et al. Identification of 2 novel ANTXR2 mutations in patients with hyaline fibromatosis syndrome and proposal of a modified grading system. Am J Med Genet A 2012;158A:732-42.

11 Nofal A, Sanad M, Assaf M, et al. Juvenile hyaline fibromatosis and infantile systemic hyalinosis: a unifying term and a proposed grading system. J Am Acad Dermatol 2009;61:695-700.

Copyright 2015 BMJ Publishing Group. All rights reserved. For permission to reuse any of this content visit

http://group.bmj.com/group/rights-licensing/permissions.

BMJ Case Report Fellows may re-use this article for personal use and teaching without any further permission.

Become a Fellow of BMJ Case Reports today and you can:

- Submit as many cases as you like

- Enjoy fast sympathetic peer review and rapid publication of accepted articles

- Access all the published articles

- Re-use any of the published material for personal use and teaching without further permission

For information on Institutional Fellowships contact consortiasales@bmjgroup.com

Visit casereports.bmj.com for more articles like this and to become a Fellow 